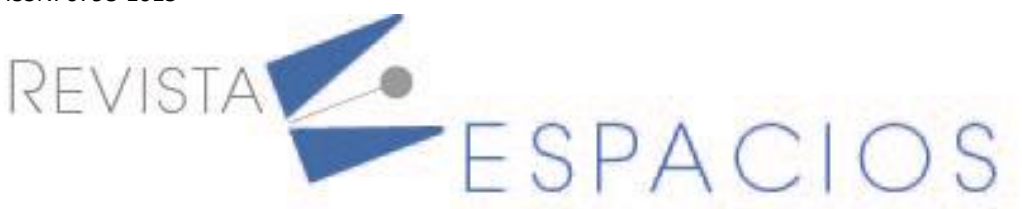

Vol. 41 (43) 2020 • Art. 3

Recibido/Received: 15/07/2020 • Aprobado/Approved: 15/08/2020 • Publicado/Published: 12/11/2020

\title{
Quality of Services in the context of the tourism enterprise development in Presov Region (Slovakia)
}

\section{Calidad de los servicios en el contexto del desarrollo de la empresa turística en la región de Presov}

\author{
HVIZDOVÁ, Eva ${ }^{1}$ \\ AMBROZY, Marián² \\ ŠAGÁT, Peter ${ }^{3}$
}

\begin{abstract}
The article deals with the quality of services provided, which greatly influence the development of tourism enterprises. The research reports on the quality of the services provided in terms of material equipment and personal security. Respondents assess the infrastructure and amenities of the region in a number of areas, with the range of catering and accommodation services as well as transport availability being evaluated very well.

Keywords: tourism enterprise, quality, quality system

Resumen

El artículo aborda la calidad de los servicios prestados, elemento que influyen en gran medida en el desarrollo de las empresas turísticas. La investigación proporciona información sobre la calidad de los servicios prestados en términos de equipamiento material y seguridad personal. Los encuestados evalúan la infraestructura y los servicios de la región en varias áreas, así como la gama de servicios de restauración y alojamiento, y la disponibilidad de transporte.

Palabras clave: empresa turística, calidad, sistema de calidad
\end{abstract}

\section{Introduction}

The tourism region is in the broadest sense the territory in which it functions functionally and organically following economic and social activities, using specific natural, demographic (human) and economic resources. Certain areas or sub-regions are considered to be tourism region. It is important to prevent the promotion of individual interests of entrepreneurs at the expense of the quality and complexity of services in the tourist resorts or region as a whole; incoordination of business activities, conflicts of interest, ineffective marketing and failure to comply with environmental protection requirements (Patus, 1997, pp. 5-7). At present, tourism is rated internationally as an important economic sector with a strong influence on the economy of the state and its individual regions. In some countries, it is among the main macroeconomic indicators. Its economic function has been emphasized as an activating factor of the economy and the development factor of the regions. According

\footnotetext{
${ }^{1}$ College of International Business ISM Slovakia in Prešov, Slovak Republic. E-mail: hvizdova@ismpo.sk

${ }^{2}$ College of International Business ISM Slovakia in Prešov, Slovak Republic. E-mail: ambrozy@ismpo.sk

${ }^{3}$ Prince Sultan University, Riyadh, Saudi Arabia. E-mail: sagat@psu.edu.sa
} 
to the possibilities and prerequisites of our country for tourism, this sector could help improve the economic situation of inhabitants in many regions. One of these regions could in the future be Prešov self-governing region, which is very suitable for the development of tourism in terms of landscape potential represented mainly by natural and cultural-administrative localization (Rosič, Mika, Klamár, 2009).

"Concerning the new Member States of the European Union, there is a recommendation for further elimination of the tax burden on corporations" (Kotlán, Machová and Janíčková, 2011, p. 638). There is no law or regulation in the Slovak Republic that would precisely define a binding list of business activities. The business activity can be determined either according to the trade license of the entity or according to the statistical classification of economic activities. Both of these factors are interconnected. These enterprises are predominantly small and medium-sized enterprises. According to Lesáková (2008, p. 607) "small and medium-sized enterprises face a need for a strategic response to changes in the global business environment". The article of this author draws attention to the 3 round benefits of a new business model that identifies the success of an enterprise by implementing new types of business, implementing innovation, information technology, and implementing strategic management. "Limited rationality is also objective in micro-enterprises and very small enterprises, but worse is the fact that these enterprises are also the result of insufficient quantitative analyzes, low levels of knowledge and the use of analytical tools" (Jankelová, Mišúnová Hudáková, Mišún, 2013, p. 753).

\section{1. Entrepreneurship in tourism towards quality}

The development of tourism in the region is conditioned by the provision of quality services. It is conditio sine qua non, without services, tourism is also severely restricted even in the case of highly attractive components that are found in the country. "It is necessary to understand the nature of strategic planning, and the stages and methods of strategy development, as well as to use foreign experience in order to conduct efficient strategic planning in domestic enterprises" (Zhuravel, 2017, p. 108). Tourism, belonging to the service sector, represents an over half or the two-thirds share of the national economy sector of some advanced economies, and can take a strategic position in the country's economy. As a whole, it has a high dynamism and is a fast-growing service. Individual countries that have understood the importance of tourism as a tool for regional development, promoting employment, its cultural and social benefits, and the economic benefits, treat its management differently. However, this complicated process is governed by commonly used criteria based on the theory of tourism management (Pardupova, 2013, p. 9). We understand this as a process of creating and further actively developing entrepreneurially oriented behaviour of any social system (Gučík, 2010). Environmental management is also part of tourism management, resulting from ethical, moral, political and social reasons. The polluted environment can be a serious obstacle to building tourism in the microregion (Fazekaš, Fazekašová, Hronec et al., 2018). Although individual devices affect only a small part of the overall environment; saving, optimization and various measures can contribute to improving the environment at local level as well as to addressing the main global challenges (Patus, 2005, p. 95). "While in the past one of the main criteria for selecting a particular tourist destination was the quality of the services provided, especially accommodation and meals, today the travel experience has become a priority theme. This fact is due, on the one hand, to a generally higher standard of service, but mainly to the fact that more and more demanding and experienced tourists prefer feeling experience to service" (Gregorová et al., 2015). The interdependence of tourism services has a significant impact on its management. The bases of its management are essential to be linked with the product features and the product of tourism itself. At present, marketing via internet must not be forgoten. "Due to the arrival of Internet, the structure of travel industry intermediation has significantly been changed" (Hikkerová, 2010, p. 45). The essential features characteristic for all types of services include: non-material service, product overdue, high consumption of human labour, combination of supply and demand (internal factors of production and external factor); - integration of the external factor (consumer) into the service production process and reconciliation of service provision and its consumption. Special features of services affecting the management and specificities of 
tourism are: the primary position of the product in product structure offering (primary offer = the destination is an important part of the product and a decisive factor in the development of tourism in the destination). Furthermore, it is the local and time conditionality of the services and their seasonality, complementarity and complexity of services, the multidisciplinary nature of services and the necessity of their mediation, the necessity of providing information about services while the visitor generates the product to a large extent himself (Gúčik, 2010, pp. 10-13). Quality assessment of tourism services has a Slovak nationwide dimension in which the Slovak quality system plays an important role. The Slovak Quality of Services in Tourism (SQST) is an innovative and voluntary tool for tourism organizations able to systematically help to improve service quality, acquire expertise and increase the competitiveness of these organizations. SQST is a tool of the state tourism policy, which serves to support the development and improvement of the quality of services provided in this area, based on simple principles of quality management resulting from the knowledge of the customer's needs and constant improvement of the quality of the services provided by the organizations involved in tourism. Organization involvement into the system will enable them to acquire expertise and practical experience in the field of quality management in services that they can further use in their own development. Successful organizations gain a prestigious, internationally comparable brand that represents a promise of service quality for the customer, as well as an appreciation of the work of all employees of the organization. The implementation of the Slovak Quality of Services in Tourism (SQST) is regulated by the SQST Standard issued by the Ministry of Transport and Construction of the Slovak Republic. Due to the wide range of tourism organizations that can be certified, the Slovak quality system for tourism services has been developed as a multilevel one: The main objective of SQST is to introduce quality management into the life of the organization, its understanding and constant development. In the first stage, the organization will adopt six simple principles of quality care and, through the action plan, will bring these principles to life in their organization. The main objective of the II grade of SQST is the further development of the first-level system and the verification of the achieved level of quality of the services provided. The Ministry of Transport and Construction of the Slovak Republic is the implementer and gestor of the Slovak Quality System for Tourism Services. The system is based on the strategic goal of the Tourism Development Strategy by 2020, which is to "increase the competitiveness of tourism by making better use of its potential, with a view to tackling regional disparities and creating new jobs". Activities to improve the quality of services in tourism enterprises are one of the elements that should contribute to the fulfillment of the stated strategic goal (MDaV SR). Control is closely related to the quality of tourism services. The control of tourism enterprises is linked to in-house economic management and allows for more efficient and effective management of business activities (Gúčik, Šebová, Bajaník, 2015, p.11). It is built on managerial approach and leads to qualified counseling by managers (Gúčik, Patúš, Šebová, 2007, p. 9). It represents a specific form of work with information and its role is not to direct real processes, but the whole enterprise through information about real processes (Pachingerová et al., 2016, p.7). In their study, the authors' team paid attention to the quality control of costs in small and medium-sized enterprises, and their research was based on a model of prevention, evaluation and failure, creating an appropriate model of quality control. "Measuring company performance by means of generally accepted indicators is a source to key information on company efficiency and its future prospects" (Mihalčová, Gallo, Pružinský, 2017, p. 79). SME managers use indicators to monitor process performance and production quality, while not creating a separate framework for measuring and assessing quality costs (Šatanová et al., 2015, p. 1146). Quality in tourism businesses is closely linked to human resources that represent a competitive advantage for a given business. "In mature markets, the information search mechanism of the consumer for purchase decisions includes personal sources where word of mouth communication (WOM) has an important influence on decisions, judged by the diffusion process" (Mookerjee, 2001, p. 177). 


\subsection{Tourist potential of the Presov region}

The tourist potential of the Presov region is immensely rich. Natural attractions are concentrated mainly in the mountains that are in this region. These are especially the High and Belianske Tatras, which offer not only a wide range of hiking trails, but also various tourist services of diverse character. There are numerous mountain lakes that are still in morpho-dynamic processes (Tomko-Králo, Kapusta, Bugár et al., 2017). There are about 85 mountain lakes in the High Tatras in the Prešov region. "Mountain natural lakes belong to the most beatiful natural formations in the Tatra National Park" (Jakubis, 2018, p. 414). The Tatras in the Prešov Region have a comprehensive range of tourist services that can be used in every season. There are also other interesting mountain ranges in the region, especially Pieniny and Poloniny. "The Pieniny Klippen Belt (PKB) is a narrow structure delineating the boundary between the Central and Outer Carpathians" (Jurewicz, 2018, p. 245). The National Parks of the Low Tatras and Slovak Paradise also have a partial impact on the Prešov Region, which have high tourist potential and adequate coverage of services.

The territory of the Prešov region is also remarkable from the historical point of view. Archaeological discoveries in our century illustrate the existence of social structures at the end of antiquity. "A wooden built tomb that dates back to $380 \pm 27$ AD was discovered in Poprad - Matejovce, Northern Slovakia in 2005" (Belanová, Pieta, 2007, p. 18). The local presentation of the discovery at European level is at the stage of preparation. During the Middle Ages, some fortified castles were built, whose buildings or ruins are a popular tourist destinations. In the territory of the region in question, it is mainly Stará Ĺubovňa, Zborov, Kapušany, Brekov, Šariš, Plaveč, Čičava, Kežmarský castle and smaller castles in Obišovce, Šebeš, Zbojnícky hrad, Bodoň, Hanigovce, and Jasenov. An important historical portfolio can be found in the historical towns such as Prešov, Sabinov, Poprad, Kežmarok, Spišská Sobota, Levoča, Ĺubica, Spišská Belá, Stará Ĺubovňa, Podolínec, and villages Velka, Hniezdne, Tvarožná etc. Above all, not all of the small towns mentioned above have a service offer corresponding to their historical and architectural potential.

In terms of agrotourism, many municipalities in the Prešov region are particularly useful, especially those with interesting folk architecture. Several demonstrative examples can be mentioned, such as Ždiar, Lipovce, Lačnov, Šindliar, Šuňava, Lendak, Matysová, Osturňa, and Liptovska Teplička. The Museums of Folk Architecture in Stara Lubovna, Bardejovske Spa, Svidnik, Humenne are also located in the region. Some of the villages have remarkable churches. The most popular are wooden churches in the towns and villages of Kežmarok, Bodružal, Ladomirova, Hervartov, Hunkovce, Korejovce, Príkra, Varadka etc. There are 26 wooden churches in the region. The pilgrimage places Levočská hora and Litmanová also serve religious tourism. Remarkable brick churches are found, for example, in the towns and villages of Poprad, Kezmarok, Starý Smokovec, Sabinov, Spisska Bela, Spišská Kapitula, Ĺubica, Markušovce, Krivany. Interesting monasteries are in Podolínec and Červený Kláštor localities, in the villages and towns of Strážky, Fričovce, Hanušovce, Markušovce, Humenné and Bijacovce etc.

The intellectual heritage of the region can be considered unique and usable even in the context of tourism. Evangelical secondary education, which was concentrated in Prešov, Bardejov and Strážky, was significant. Prešov also developed a branch of Slovak higher education, also important for the history of philosophical thinking in Slovakia (Dupkala, 2009). Historic buildings have remained, but the relevant exposure related to the intellectual heritage of Evangelical secondary education is only found in Strážky. Apart from the mentioned location with the exposition, tourists can admire only buildings and memorial boards, here we see a reserve in the area of services, and specialized expositions devoted to the intellectual heritage of schools in Prešov and Bardejov would definitely become more attractive places for tourists. 


\section{Methodology}

Various methods were used to prepare this study. In the beginning, we used a narrative method to present the problem of regional tourism in relation to services and the environment. We briefly present the Slovak Quality of Services in Tourism as a two-level system and tool for the state tourism policy. We present the tourist potential of the region by the same method. On the one hand, we draw on the natural resources of the region, as well as on the rich history. In a short portfolio, we present national parks, castles, historic towns, villages with remarkable folk architecture.

In the survey, we examined the quality of services provided in the field of tourism in Eastern Slovakia. The survey was carried out using the questionnaire method, and it was attended by 586 respondents. The evaluation of provided services, as well as the evaluation of equipment and infrastructure of the region evaluation, were summarized in a table. We further verbally analyzed the price level of services, objects of interest, the attractiveness of the region, and shortcomings in services based on the questions.

Another survey method was data detection from the Statistical Office of the SR. We focused our attention on the Prešov region. We compared the year-on-year growth of visitors, the average length of accommodation, the percentile of foreign visitors, the strongest location, and other regions of the Slovak Republic. the possibilities of religious tourism were analyzed too.

\section{Results}

The aim of the research was to find out how the quality of the provided services is perceived by the participants in tourism in the territory of the East Slovak region. As a research method, a questionnaire was used. The survey was conducted in the course of 2018. 586 respondents were approached, of whom 194 were men and 392 were women, 53\% were from another city in Slovakia, 33\% from another country, and $7 \%$ were from close and distant places from regions of Prešov, Košice, Banská Bystrica, Bratislava and Nitra. As a means of transport, respondents put their own car (53\%), bus transport (33\%) and $7 \%$ bicycle and train transport. $40 \%$ of the addressed visited alone the East Slovak region, $34 \%$ with a partner and $13 \%$ with the family and friends.

Table 1

Evaluation of services provided in the Presov region

\begin{tabular}{|l|c|c|c|c|c|}
\hline \multicolumn{1}{|c|}{ Evaluation of CR services } & $\begin{array}{c}\text { very } \\
\text { well }\end{array}$ & $\begin{array}{c}\text { rather } \\
\text { well }\end{array}$ & $\begin{array}{c}\text { rather } \\
\text { bad }\end{array}$ & $\begin{array}{c}\text { very } \\
\text { bad }\end{array}$ & $\begin{array}{c}\text { I cannot } \\
\text { judge }\end{array}$ \\
\hline providing information about the region & $13 \%$ & $20 \%$ & $13 \%$ & $20 \%$ & $34 \%$ \\
\hline friendliness of local people & $60 \%$ & $20 \%$ & $0 \%$ & $0 \%$ & $20 \%$ \\
\hline care for cleanliness and order & $33 \%$ & $60 \%$ & $7 \%$ & $0 \%$ & $0 \%$ \\
\hline accommodation services & $13 \%$ & $54 \%$ & $13 \%$ & $0 \%$ & $20 \%$ \\
\hline staff level & $13 \%$ & $34 \%$ & $0 \%$ & $\%$ & $53 \%$ \\
\hline level of catering services & $60 \%$ & $33 \%$ & $7 \%$ & $0 \%$ & $0 \%$ \\
\hline
\end{tabular}

Respondents evaluated the services provided in the region (Table 1), with the greatest deficiencies in providing information on the region, which represented approximately $33 \% .13 \%$ badly rated the accommodation. Level of catering services (93\%) was evaluated surprisingly very well and rather well and the friendliness of local people $(80 \%)$. The evaluation of the infrastructure and amenities of the region (Table 2) in the area of catering and accommodation services was $87 \%$ and very well (100\%) was evaluated transport availability, which was very surprising from the point of view of the most frequent criticism at national level. Visitors criticized the signs of hiking or skiing routes. 
Table 2

Evaluation of the infrastructure and

facilities of the Presov region

\begin{tabular}{|c|c|c|c|c|c|}
\hline $\begin{array}{l}\text { Evaluation of infrastructure and regional } \\
\text { amenities in the areas }\end{array}$ & $\begin{array}{l}\text { very } \\
\text { well }\end{array}$ & $\begin{array}{l}\text { rather } \\
\text { well }\end{array}$ & $\begin{array}{l}\text { rather } \\
\text { bad }\end{array}$ & $\begin{array}{l}\text { very } \\
\text { bad }\end{array}$ & $\begin{array}{l}\text { I cannot } \\
\text { judge }\end{array}$ \\
\hline Range of catering and accommodation services & $60 \%$ & $27 \%$ & $6 \%$ & $0 \%$ & $0 \%$ \\
\hline Transport accessibility of the region & $40 \%$ & $60 \%$ & $0 \%$ & $0 \%$ & $0 \%$ \\
\hline Marking of hiking / ski trails & $7 \%$ & $20 \%$ & $23 \%$ & $0 \%$ & $50 \%$ \\
\hline Marking the monuments, attractions & $27 \%$ & $40 \%$ & $0 \%$ & $0 \%$ & $0 \%$ \\
\hline Sport facilities of the region & $0 \%$ & $60 \%$ & $7 \%$ & $0 \%$ & $33 \%$ \\
\hline Small sales, souvenirs, stands & $20 \%$ & $40 \%$ & $0 \%$ & $0 \%$ & $40 \%$ \\
\hline
\end{tabular}

Respondents regard the region in terms of the price level of services as about as much as elsewhere in Slovakia, only two percent of them consider it cheaper than elsewhere in Slovakia. A re-visit to the region is about 7\%, $53 \%$ certainly later, $20 \%$ rather early, and $20 \%$ of the respondents have failed to answer this question in the shortest possible time. The region is most attracted by historic buildings, Zoo, cultural and historical monuments, sightseeing towers and shopping centers. The region's attractiveness from a tourism perspective is higher than expected or as expected. In their opinion, the region is most lacking in quality infrastructure: roads, parking, setout, then better care of historical monuments and attractions and social and entertainment centers. The most attractive activity during their stay has been their participation in cultural and folklore events, social life and entertainment, water sports and motoring events.

According to data from the Statistical Office of the SR, 894173 visitors to the Prešov region were recorded in 2017 in accommodation facilities, who spent 2790308 nights in the region. Visit to Prešov Region was increased by $4.6 \%$ year-on-year. The year 2016 with 854528 visitors was a record in the number of visitors to the Prešov Region, but the year 2017 surpassed it by almost 40000 visitors. The average stay was three nights. Foreign visitors accounted for $31 \%$ of the total number of visitors. For the year 2017 , their number grew by $2.4 \%$ to 276,666 foreign visitors. In the county, they spent 823,223 nights (Čechová, 2018a). During the first half of 2018, Prešov Region was visited by 437,638 visitors as recorded in accommodation facilities. This is an increase of $6.3 \%$ on year-on-year scale. At the same time, the Prešov region recorded the highest number of nights spent by domestic tourists in all the Slovak regions in the first half of 2018, according to the Statistical Office of the Slovak Republic. From January to the end of June $2018,437,638$ visitors spent the night in the Prešov region. The average stay was three nights. Tourists spent 1,311,394 nights in the region. The strongest attraction is the locality of the High Tatras. Compared to the first half of 2017, the total increase in the number of visitors in the Prešov region is $6.3 \%$. The average number of visitors per day is $3.6 \%$. The Prešov Region is the third most visited region in Slovakia (after the Bratislava and Žilinský Regions). While some regions experienced a drop in domestic visitors, on the contrary, the Prešov region attracted 18,257 Slovaks more than in 2017 (6.1\% increase). The Prešov Region reached the highest number of nights spent in the first half of the year ( $22 \%$ in the whole SR). The Slovaks spent 954,798 nights in the region, staying on average for three nights. Nearly $28 \%$ of visitors in the first half of the year 2018 in the Prešov Region were foreign tourists. Totally, 120,748 people came to the accommodation facilities, with an average stay of three nights. Even here the number grew year-on-year, namely by $6.8 \%$. From the point of view of foreign visitors, the region is the third most visited in Slovakia (Čechová, 2018b). 


\section{Conclusions}

The quality of tourism services in terms of the involvement of the corresponding enterprises is determined by the volume of tourism. Tourism itself is an important indicator in selected countries in terms of macroeconomics. We have shown that the potential of the Prešov region is really high for tourism. The region also has opportunities for the development of religious tourism. "The Prešov region is attractive in this respect, with a large number of places, buildings and significant pilgrimage sites appealing to domestic and foreign visitors due to their nature or historical value" (Štefko et al., 2014, p. 1796). The process of integrating tourism as a tool for regional development is complex. As part of the tourism evaluation, the Slovak System of Quality of Services in Tourism (SQST), which is a tool of state policy, plays an important role. It is based on the identification of the real needs of the customer and the SQST Standard is the Legislative Standard for CQST. The quality system in question is multi-level, the first level includes quality assurance principles, the second level is the development of the system and the verification of its quality. In the field of tourism, control is linked to the internal economic management of the enterprise. In tourism, a quality is associated with human resources. Qualitative research evaluated services in the region, with significant deficiencies in offering information on region (33\%). Ferencová et al. also draw attention to the importance of this component in the region in question (Ferencová et al., 2016). Accommodation services (13\%) were in the second negative place. Catering and friendliness were $93 \%$ and $80 \%$ positive. Infrastructure and amenities in the region received $87 \%$ and very well and rather well (100\%) was perceived transport accessibility, but transport and ski routes obtained negative ratings. Around $80 \%$ of respondents would return to the region as part of tourism. According to statistics in 2017, the county visited 894,173 visitors who spent 2,790,308 in it, with visitors increasing year-on-year by $4.6 \%$. In the first half of 2018, the region hosted 437,638 visitors, which is a year-on-year increase of $6.3 \%$, which is $6.1 \%$ year-on-year growth of domestic visitors.

The article is the output of the project IG-KEMM-01/2017/3.3.9.

\section{References}

Belanová, T., \& Pieta, K. (2007). Discovery of a unique chamber tomb in Poprad - Matejovce (Slovakia). Archeological Textiles Newsletter 44, 18-20.

Čechová, B. (2018a). Návštevnost' v Prešovskom kraji opät rástla. Retrieved from: //www.severovychod.sk/clanok/navstevnost-v-presovskom-kraji-opat-vzrastla

Čechová, B. (2018b). Počet návštevníkov Prešovského kraja v prvom polroku opät vzrástol. Retrieved from: www.po-kraj.sk/sk/samosprava/aktuality/2018

Dupkala, R. (2009). Philosophizing in Slovakia: Reflections and contexts (on the receptivity of the philosophical thought in Slovakia). Filozofia 64 (6), 552-559.

Fazekaš, J., Fazekašová, D., Hronec, O., Benková, E., \& Boltižiar, M. (2018). Contamination of soil and vegetation at a magnesite mining area in Jelšava - Lubeník (Slovakia). Ekologia Bratislava 37 (2), 101 - 111

Ferencová, M., Ślusarczyk, B., Kot, S., \& Mišenčíková, V. (2016). The use of E-communication in promoting selected religious, cultural and historical monuments in Presov in the East of Slovakia. In: Lecture Notes of the Institute for Computer Science, Social - Informatics and Telecommunications Engineering LNICST Volume 170, 129-135

Gregorová, B., Neradný, M., Klaučo, M., Masný, M., \& Balková, N. (2015). Cestovný ruch a regionálny rozvoj. Banská Bystrica: Belianum, 197 p. 
Glúčik, M. a kol. (2010). Manažment cestovného ruchu. Banská Bystrica: Dali-BB. 152 p.

Glúčik, M. a kol. (2012). Manažment ciel’ového miesta cestovného ruchu. Banská Bystrica: Dali-BB. 219 p.

Glúčik, M., a kol. (2017). Manažment regionálneho cestovného ruchu. Banská Bystrica: Dali-BB. 290 p.

Glúčik, M., Patúš, P., \& Šebová, L'. (2007). Kontroling podnikov cestovného ruchu. Banská Bystrica: Dali-BB. 177 p.

Glúčik, M., Šebová, Ĺ., \& Bajaník, T. (2015). Kontroling podnikov cestovného ruchu. Bratislava: Wolters Kluwer. $230 \mathrm{p}$.

Hikkerová, L. (2010). E-tourism: Players and customer behavior. In: Problems and Perspectives in Management 8 (spec. iss. 4), 45-51.

Jakubis, M. (2018). Unique natural mountain lakes in Tatra National Park-Tourism and nature protection hand in hand?. Public Recreation and Landscape Protection - With Nature Hand in Hand? Conference Proceeding, pp. 414-419.

Jankelová, N., Mišúnová Hudáková, I., \& Mišún, J. (2013). Význam strategického rozhodovania v mikropodnikoch a vel'mi malých podnikoch na príklade Slovenskej republiky. Ekonomický časopis 61 (7), 737-756.

Jurewicz, E. (2018). The Šariš Transitional Zone, revealing interactions between Pieniny Klippen Belt, Outher Carpathians and European platform. Swiss Journal of Geosciences 111 (1-2), 245-267.

Klamár, R., Mika, M., \& Rosič, M. (2009). Regionalne aspekty rozwoju turystyki na Slowacji, na przykladzie Preszowskiego kraju. Gospodarka i przestrzen : prace dedykowane Profesor Danucie PtaszyckiejJackowskiej. Kraków : Uniwersytet Jagiellonski, 169-185.

Kotlán, I., Machová, Z., \& Janíčková, L. (2011). Taxation influence on the economic growth. Politická ekonomie 59 (5), 638-658.

Lesáková, L., (2008). Influence of globalisation on small and medium enterprises. Ekonomický časopis 56 (6), 607-621.

Mihalčová, B., Gallo, P., Pružinský, M. (2017). Measurement of company performance in a health resort in Slovakia taken as an example. Quality - Acess to Sucess 18 (158), $79-84$.

Mookerjee, A. (2001). A Study of the Influence of Source Characteristics and Product Importance on Consumer Word of Mouth Based on Personal Sources. Global Business Review 2 (2), 177 - 193.

Pachingerová, M. (2016). Kontroling podnikov cestovného ruchu. Bratislava: Ekonóm. 295 p.

Pardupová, R. (2013). Vývoj a rozdiely v riadení cestovného ruchu na národnej úrovni medzi Českom a Slovenskom. Praha: Vysoká škola hotelová v Praze. 94 p.

Patúš, P. (1997). Manažment regiónu a strediska cestovného ruchu. Banská Bystrica: Cestovatel'. 160 p.

Patúšs, P., \& Glúčik, M. (2005). Manažment ubytovacej prevádzky hotela. Banská Bystrica: Slovensko-švajčiarske združenie pre rozvoj cestovného ruchu. $126 \mathrm{p}$.

Rosič, M., \& Klamár. R. (2009). The potential of tourism in the Prešov county regions. Folia geographica Prírodné vedy 49 (14) (special issue for the 2th Eugeo Congress Bratislava 2009), 249 - 270. 
Šatanová, A., Závadský, J., Sedliačiková, M., Potkány, M., Závadská, Z., \& Holíková M. (2015). How Slovak small and medium manufacturing emterprises maintain quality cost: an empirical study and proposal for a suitable model. Total Quality Management and Business Excellence 26 (11-22), 1146-1160.

Štefko, R., Királ'ová, A., Mudrík, M., \& Matušíková, D. (2014). Preconditions for using marketing communication on social networks in religious and pilgrimage. Proceedings of the 24th International Business Information Management Association Conference - Crafting Global Competitive Economies: 2020 Vision Strategic Planning and Smart Implementation2014, 1796-1808.

Slovenský systém kvality. (2018). Ministerstvo dopravy a výstavby Slovenskej republiky. Retrieved from: http://www.systemkvalitycr.sk/sk/o-systeme/

Tomko-Králo, D., Kapusta, J., Bugár, G., Sedlák, A., \& Hreško, J. (2017). Lake shoreline changes of the selected lakes in High Tatras (1949 - 2015). International Multidisciplinary Scientific GeoConference Surveying Geology nad Mining Ecology Management SGEM Volume 17, Issue 23, 163 - 170.

Zhuravel, Y. (2017). Application of foreign experience in strategic planning by domestic enterprises. Perspectives - Journal on Economic Issues 3 (1), 107 - 116.

Esta obra está bajo una Licencia Creative Commons Attribución-NoCommercial 4.0 International

(cc) BY-NC 